J. Product. \& Dev., 20(2): $161-177(2015)$

\title{
INHERITANCE OF SOME YIELD COMPONENTS AND GRAIN QUALITY TRAITS IN RICE (Oryza sativa L)
}

\author{
Khaled, F. M. Salem *, Y. M. Yaseen*, A. B. El-Abd** and A. Ayoub* \\ - Plant Biotechnology Department, Genetic Engineering and Biotechnology \\ Research Institute, Sadat City University, Sadat City, Egypt. \\ **Rice Research Section, Field Crops Research Institute, ARC, Giza, Egypt.
}

\section{ABSTRACT}

The investigation was laid out at the Experimental Farm of Rice Research and Training Center (RRTC), Sakha, Kafer EL-Sheikh, Egypt, during three successive rice growing seasons, 2010, 2011 and 2012.The study aimed to fin the effect of gene action in the inheritance of grain yield, its components and some rice grain quality traits under normal conditions. The materials for this study consisted of six rice genotypes namely; Sakha101, Sakha102, Egyptian Yasmin, GZ1368s5-4, IET1444 and IR78875-176-B2-B, These genotypes have a wide range of variation due to their different genetic background. The six rice parents were crossed to produce $F 1$ hybrid seeds of three crosses, namely, Sakha101 x GZ1368s-5-4, Sakha102 x IET1444 and Egyptian Yasmin $x$ IR78875-176-2B. The six populations, P1, P2, F1, F2, BC1 and $B C 2$ for each cross were utilized to determine the genetic parameter of the studied characters.

The results revealed that mid parent values $(m)$ were highly significant in positive direction for all traits in all crosses, Moreover, additive effect was highly significant in negative direction for grain yield/plant trait in cross I, as well as, grain length, grain shape and amylose content \% in cross II. In addition, dominance effect was played an important role in the inheritance of grain shape, and amylose \% in negative direction and grain yield in positive direction in cross III. These results also indicated that all types of gene interaction were played an important role in the inheritance of all traits, according to the cross itself.

The broad sense heritability was high for all traits, it was ranged between (85.51 and $98.73 \%$ ) for 1000 grain weight in cross I and grain yield/plant in cross I, respectively. Moreover, low to moderate estimated values of narrow sense heritability were observed for all traits in all crosses, the highest value (32.5\%) was recorded for grain shape trait in cross III. However, the great discrepancy between the estimates of heritability in broad and narrow sense for 1000-grain 
weight character was reflected in low estimates of dominance variance or high estimates of additive variance for this trait. In addition, low estimates of expected genetic advance (9.03 and 9.04) were observed for amylose \%, and 1000-grain weight in cross I, respectively. Low to moderate expected genetic advance with low narrow sense heritability for amylose content \% and 1000-grain weight could be expected because this trait is under polygenic control. Moreover, additive and dominance components of variation were significant in the inheritance of these traits, but additive component was higher than the dominance one.

Conclusively, the results suggested that early generation selection may be effective in improving of these traits in cross I. On the other hand, the results also indicated that the selection in late generations will be improving grain shape in cross II and 1000 grain weight in cross III.

Key words: Rice, Inheritance, Gene action, Yield components and Grain quality traits.

\section{INTRODUCTION}

Rice is one of the most important food crops in the world. It is estimated that 40 per cent of the world's population take rice as their major source of food. The advent of higher yielding semi dwarf varieties has been instrumental in achieving consistent progress in rice production in the past three decades and attaining self-sufficiency.

Rice is a highly self-fertilized plant, which means that pollen from the same flower or from another flower on the same plant will pollinate itself. Pollen is shed from the stamens and lands on the pistil of either the same flower or another flower of the same plant over $95 \%$ of the time.

In Egypt, rice is considered as one of the most important field crops, since it contributes about $20 \%$ of the total cereal consumption. Annually, more than one and half million feddans is cultivated with rice (one feddan = $4200 \mathrm{~m} 2$ ) producing about 6.5 million tons of rice, with an average of 4.6 ton/fed. (10.9 ton/ha) (RRTC, 2013).

Success in crop improvement generally depends on the magnitude of genetic variability and the extent to which the desirable characters are heritable. Development of high-yielding varieties requires a thorough knowledge of the existing genetic variation for yield and its components and grain quality traits. The observed variability is a combined estimate of genetic and environmental causes, of which only the former one is heritable. However, estimates of heritability alone do not provide an idea about the 
expected gain in the next generation, but have to be considered in conjunction with estimates of genetic advance. Grain yield character in rice is quantitative trait in nature and is polygenically controlled. Selection on the basis of grain yield character alone is usually not very effective and efficient. However, selection based on its component characters could be more efficient and reliable. Quality is defined as a major factor which decides market values of agricultural products and foods in each phase from production through consumption. Rice grain quality has always been an important consideration in rice variety selection and development, it is second only to yield as a major breeding and thus relates to a number of factors, while the cooking and eating quality is a part of the factors in assessing the grain quality of rice. In the future, grain quality will be even more important once, the very poor-many of whom depend largely on rice for their staple food become better off and begin to demand higher quality rice.

Estimation of the types of gene action involved in the expression of traits, the level of additive effects, and the degree of dominance are very important in developing a breeding method for the trait of interest, Hallauer and Miranda (1988). Alleles with dominance or additive phenotypic effects influence heritability differently, depending on whether they are in homozygous or heterozygous conditions. Knowledge of the way genes act and interact will determine which breeding system can optimize gene action more efficiently, and will elucidate the role of breeding systems in the evolution of crop plants.

This investigation aimed to determine mode of inheritance and type of gene action and genetic effects of genes and to estimates of genetic variance, broad and narrow sense heritability and genetic advance for yield and grain quality traits.

\section{MATERIALS AND METHODS}

The present study was laid out at the Experimental Farm of Rice Research and Training Center (RRTC), Sakha, Kafer EL-Sheikh, Egypt, during three successive rice growing seasons, 2010, 2011 and 2012 to study the effect of gene action in the inheritance of grain yield, its components and some rice grain quality traits. The materials for this study consisted of six rice genotypes namely; Sakha101, Sakha102, Egyptian Yasmin, GZ1368s-5-4, IET1444 and IR78875-176-2B, These genotypes have a wide range of variation due to their different genetic background.

The six rice parents were crossed to produce $F_{1}$ hybrid seeds of three crosses. These three crosses were Sakha101 x GZ1368s-5-4, Sakha102 x IET1444 and Egyptian Yasmin $x$ IR78875-176-2B. The six populations, $\mathrm{P}_{1}$, 
$\mathrm{P}_{2}, \mathrm{~F}_{1}, \mathrm{~F}_{2}, \mathrm{BC}_{1}$ and $\mathrm{BC}_{2}$ for each cross were utilized to determine the genetic parameter of the studied characters.

In 2010 season, the parental genotypes were grown at RRTC farm in three planting dates with ten days interval in order to overcome the differences in flowering time between parents. Thirty days old seedling of each parent was individually transplanted in the field in 10 rows. Each row was $5 \mathrm{~m}$ long and included 25 hills. At flowering time, hybridization between parents was carried out following the technique proposed by Jodon (1938) and modified by Botany (1961) and the aforementioned three crosses were produced.

In 2011 season, parents and $F_{1}$ hybrid seeds of the three crosses together with their parental lines were planted under normal conditions. At heading, parents were crossed again to produce the $F_{1}$ hybrid seeds of three crosses following the same technique. Moreover, some of $F_{1}$ plants were left to be self-pollinated in order to produce $\mathrm{F}_{2}$ seeds, while some other plants were crossed with their own parents as a male to produce $\mathrm{BC}_{1}$ and $\mathrm{BC}_{2}$ seeds. At harvest, seeds of different generations were individually harvested to be grown in the next season.

Subsequently, in 2012, summer season, seeds of the $\mathrm{P}_{1}, \mathrm{P}_{2}, \mathrm{~F}_{1}, \mathrm{BC}_{1}, \mathrm{BC}_{2}$ and $\mathrm{F}_{2}$ of each cross were sown in normal conditions to estimate the genetic parameter of the seven rice agronomic characters and seven rice quality characters. Eighteen entries belongs to different generations (6 parents, 3F1's, 3F2's, 3BC1, 3BC2) were cultivated in a randomized complete block design experiment with four replication. Each replicate contained 10 rows of each $\mathrm{P}_{1}$, $\mathrm{P}_{2}, 5$ rows of each of $\mathrm{F}_{1}, \mathrm{BC}_{1}$ and $\mathrm{BC}_{2}$ and 15 rows of $\mathrm{F}_{2}$ generations. In all growing seasons of the study, all cultural practices such as field preparation, sowing method, transplanting and fertilizers, weed control were applied as recommended. Eight yield and quality rice characteristics, number of panicles/plant, 1000-grain yield, grain yield/plant, grain length, grain shape, gelatinization temperature and amylose content were measured following the standard evaluation system for rice (IRRI 1996).

The collected data were subjected to the proper statistical analysis of variance of Randomized Complete Block Design as described by Snedecor and Cochran (1967). The present data were predicted to biometrical model suggested by Mather (1949) and Hayman (1958) in order to estimate the gene actions and to separate the genetic components of variations controlling the studied characters. The scaling test of inquest is important because in most of the cases, estimation of additive and dominance components of variances are made immoderation of the gene interaction. Individual scaling test was applied to the six populations data of each cross as outlined by Mather (1949) and Hayman and Mather (1955). Expected genetic variance of $\mathrm{VBC}_{1}, \mathrm{VBC}_{2}$ 
and $\mathrm{VF}_{2}$ in terms of additive $(1 / 2 \mathrm{D})$ and dominance $(1 / 4 \mathrm{H})$ are derived by Mather (1949) as follows:

Additive genetic variance $(\mathbf{1} / \mathbf{2} \mathbf{D})=2 \mathrm{VF} 2-(\mathrm{VBC} 1+\mathrm{VBC} 2)$

$$
\text { (D) }=4 \mathrm{VF} 2-2(\mathrm{VBC} 1+\mathrm{VBC} 2)
$$

Dominance genetic variance $(\mathbf{1} / \mathbf{H} \mathbf{H})=\mathrm{VBC} 1+\mathrm{VBC} 2-\mathrm{VF} 2-\mathrm{VE}$

$$
(\mathbf{H})=4(\mathrm{VBC} 1+\mathrm{VBC} 2-\mathrm{VF} 2-\mathrm{VE})
$$

The heritability in both broad and narrow sense was determined by Powers et al (1950) and Warner (1952), respectively, as follows:

\begin{aligned} Heritability in broad sense $\left(\mathrm{h}^{2} \mathrm{bs}\right)= &$ Genetic variance $(\mathrm{VG}) \\$\hdashline & $\begin{array}{l}\text { Phenotypic variance }(\mathrm{Vph}) \\ \text { Additive genetic variance }(\mathrm{VA})\end{array}\end{aligned}$

Heritability in narrow sense $\left(\mathrm{h}^{2} \mathrm{~ns}\right)=-$----------------------

Predicted and expected values of genetic advance (GS and GS \%) were calculated according to Johnson et al. (1955).

$$
\begin{aligned}
& \mathrm{GS}=\mathrm{K} . \mathrm{h}^{2} \text { ns. } \sigma \mathrm{ph} \\
& \mathrm{GS} \%=\mathrm{GS} /{ }^{-} \mathrm{x} \times 100
\end{aligned}
$$

Where: $\mathbf{K}=$ Selection differential and equals 2.06 upon selecting the highest $5 \%$ of population, Hanson et al (1956), $\mathbf{h}^{2} \mathbf{n s}=$ Heritability in narrow sense and $\boldsymbol{\sigma p h}=$ Phenotypic standard deviation.

\section{RESULTS AND DISCUSSION}

The present data were subjected to biometrical model in order to estimate the gene action and to separate the genetic components of variations governing the studied characters besides other genetic parameters to give a complete description and full information about the inheritance of the traits under study. Gene action and genetic effects of genes, estimates of genetic variance, broad and narrow sense heritability and genetic advance were discussed as follow:

\section{1-Estimates of gene action and genetic effects of genes \\ 1000 grain weight}

Data in Table (1) showed that the values of A, B and Cof the scaling test for 1000 grain weight were highly significant in all studied crosses, indicating the important of interaction components, i.e. additive $\mathrm{x}$ additive (i) additive $\mathrm{x}$ dominance (j) and dominance $\mathrm{x}$ dominance (L) in the inheritance of 1000 grain weight.

It is clear in Table (2) that the mid parent value (m) was positively significant in the three studied crosses. On the other hand, additive effect (d) 
Table (1): Scaling test for adequacy of additive and dominance model in the three studied crosses characters.

\begin{tabular}{|c|c|c|c|c|}
\hline Character & Cross & $\mathbf{A}$ & B & C \\
\hline \multirow{3}{*}{$\begin{array}{l}1000 \text { grain } \\
\text { weight } \\
\text { (gm) }\end{array}$} & I & $-0.33 \pm 0.07 * *$ & $0.42 \pm 0.11 * *$ & $-13.95 \pm 1.9 * *$ \\
\hline & II & $3.35 \pm 0.13 * *$ & $3.34 \pm 0.13 * *$ & $24.6 \pm 3.35^{* *}$ \\
\hline & III & $57 \pm 0.26^{* *}$ & $17.34 \pm 0.27 * *$ & $24.72 \pm 8.34 * *$ \\
\hline \multirow{3}{*}{$\begin{array}{c}\text { Grain } \\
\text { yield/plant। } \\
\text { (gm) }\end{array}$} & I & $15.3 \pm 2.32 * *$ & $20.03 \pm 2.33 * *$ & $33.09 \pm 97$ \\
\hline & II & $-7.39 \pm 3.3^{*}$ & $-46 . \pm 3.82 * *$ & $64.7 \pm 91.09$ \\
\hline & III & $16.3 \pm 3.12 * *$ & $15.07 \pm 2.12 * *$ & $12.14 \pm 74.89$ \\
\hline \multirow{3}{*}{$\begin{array}{c}\text { Grain length } \\
(\mathrm{mm})\end{array}$} & $\mathbf{I}$ & $-1.16 \pm 0.019 * *$ & $0.027 \pm 0.02$ & $-3.17 \pm 0.45 * *$ \\
\hline & II & $-3.26 \pm 0.007 * *$ & $-17.45 \pm 0.05 * *$ & $-8.87 \pm 0.3^{* *}$ \\
\hline & III & $-6.86 \pm 0.14 * *$ & $-14.7 \pm 0.08 * *$ & $-10.24 \pm 0.53 * *$ \\
\hline \multirow[t]{3}{*}{ Grain shape } & I & $0.15 \pm 0.018^{* *}$ & $5.07 \pm 0.013 * *$ & $1.49 \pm 0.07 * *$ \\
\hline & II & $0.887 \pm 0.027 * *$ & $-4.22 \pm 0.021 * *$ & $-0.33 \pm 0.128 * *$ \\
\hline & III & $-1.9 \pm 0.038 * *$ & $--5.65 \pm 0.025^{* *}$ & $-1.22 \pm 0.16 * *$ \\
\hline \multirow{3}{*}{$\begin{array}{c}\text { Amylose } \\
\text { content } \\
\%\end{array}$} & I & $-2.48 \pm 0.27 * *$ & $-43.77 \pm 0.2 * *$ & $4.87 \pm 1.04 * *$ \\
\hline & II & $-17.28 \pm 0.014 * *$ & $-19.68 \pm 0.012^{* *}$ & $36.96 \pm 0.025 * *$ \\
\hline & III & $-8.08 \pm 0.076 * *$ & $-41.48 \pm 0.064 * *$ & $-10.73 \pm 0.46^{* *}$ \\
\hline
\end{tabular}

Where: Crosses I, II and III were Sakha 101 x GZ1368s-5-4, Sakha 102 x IET 1444 and Egyptian Yasmin x IR78875-176-B2-B, respectively.

*and **: Significant at $0.05,0.01$ probability levels, respectively.

was either positively (2.21) or negatively (-5.2) highly significant in crosses II and III, respectively. The genetic parameters, dominance effect (h) and additive $\mathrm{x}$ additive type of gene interaction (i) for 1000 grain weight were positive and high significant in cross I, while it was negative and highly significant in cross II. Moreover, additive $\mathrm{x}$ dominance (j) type of gene interaction was highly significant in negative direction in cross III. In addition, dominance $\mathrm{x}$ dominance (L) type of gene interaction was highly significant in negative direction in crosses, I and III, while, it was in positive direction in cross, II. The results indicated that the selection in late generations will be improving 1000 grain weight in cross III. Similar results were obtained previously by El-Hissewy (2004), Akram et al. (2007), Shehata et al. (2009) and Onyia (2011).

\section{Grain yield per plant}

Data in Table (1) showed that values of A and B in the scaling test for grain yield per plant were highly significant in all studied crosses, except, value of A in cross, II, which showed to be significant only. However, the calculated value of 
Table (2). Components of generation mean in the three studied crosses characters.

\begin{tabular}{|c|c|c|c|c|c|c|c|}
\hline \multirow{2}{*}{ Character } & \multirow{2}{*}{$\begin{array}{c}\text { Cros } \\
\mathbf{s}\end{array}$} & \multicolumn{6}{|c|}{ Genetic components of generation means } \\
\hline & & $\mathrm{m}$ & $\mathrm{d}$ & $\mathrm{h}$ & I & $\mathrm{j}$ & 1 \\
\hline $\begin{array}{l}1000 \text { grain } \\
\text { weight } \\
\text { (gm) }\end{array}$ & $\begin{array}{c}\text { I } \\
\text { II } \\
\text { III }\end{array}$ & $\begin{array}{l}27.05^{* *} \\
31.39^{* *} \\
32.32^{* *}\end{array}$ & $\begin{array}{l}-0.07 \\
2.21 * * \\
-5.2^{* *}\end{array}$ & $\begin{array}{c}20.33^{* *} \\
-19.08^{* *} \\
-2.78\end{array}$ & $\begin{array}{c}14.03 * * \\
-17.9 * * \\
-1.68\end{array}$ & $\begin{array}{c}-0.37 \\
-0.007 \\
-5.82 * *\end{array}$ & $\begin{array}{l}-14.13 * * \\
11.21^{* *} \\
-21.36^{* *}\end{array}$ \\
\hline $\begin{array}{c}\text { Grain yield / } \\
\text { plant (gm) }\end{array}$ & $\begin{array}{c}\text { I } \\
\text { II } \\
\text { III }\end{array}$ & $\begin{array}{l}56.48^{* *} \\
70.03^{* *} \\
51.35^{* *}\end{array}$ & $\begin{array}{c}3.03 * \\
20.7 * * \\
5.31^{* *}\end{array}$ & $\begin{array}{c}16.44 \\
-92.44^{* *} \\
39.24 * *\end{array}$ & $\begin{array}{c}-2.24 \\
-118.1 * * \\
19.23\end{array}$ & $\begin{array}{c}-2.37 \\
19.3 * * \\
0.61\end{array}$ & $\begin{array}{l}-37.58^{*} \\
171.5^{* *} \\
-50.6^{* *}\end{array}$ \\
\hline $\begin{array}{l}\text { Grain length } \\
(\mathbf{m m})\end{array}$ & $\begin{array}{c}\text { I } \\
\text { II } \\
\text { III }\end{array}$ & $\begin{array}{l}5.86^{* *} \\
7.85 * * \\
7.59 * *\end{array}$ & $\begin{array}{c}-0.111 \\
-0.035^{* *} \\
-0.039\end{array}$ & $\begin{array}{c}1.22 \\
-5.57^{* *} \\
-10.97^{* *}\end{array}$ & $\begin{array}{c}2.03 * \\
-7.94 * * \\
-7.49 * *\end{array}$ & $\begin{array}{c}-0.59^{* *} \\
0.088 \\
0.118\end{array}$ & $\begin{array}{c}-0.9 \\
18.13^{* *} \\
20^{* *}\end{array}$ \\
\hline $\begin{array}{l}\text { Grain } \\
\text { shape }\end{array}$ & $\begin{array}{c}\text { I } \\
\text { II } \\
\text { III }\end{array}$ & $\begin{array}{l}2.43 * * \\
2.07 * * \\
2.85 * *\end{array}$ & $\begin{array}{c}0.24 * * \\
-0.67 * * \\
0.67 * *\end{array}$ & $\begin{array}{c}1.85^{* *} \\
1.28 \\
-3.45^{* *}\end{array}$ & $\begin{array}{c}1.64 * * \\
1.72 * \\
-2.72 * *\end{array}$ & $\begin{array}{c}0.68 * * \\
-0.54 * * \\
-0.15\end{array}$ & $\begin{array}{l}-2.88 * * \\
-2.27 * \\
6.74 * *\end{array}$ \\
\hline $\begin{array}{c}\text { Amylose } \\
\text { content } \\
\%\end{array}$ & $\begin{array}{c}\text { I } \\
\text { II } \\
\text { III }\end{array}$ & $\begin{array}{l}24.39 \text { ** } \\
20.54 * * \\
21.38^{* *}\end{array}$ & $\begin{array}{c}0.23 \\
-2.4^{* * *} \\
0.084\end{array}$ & $\begin{array}{l}-15.77^{* *} \\
-5.97^{*} \\
-10.7^{* *}\end{array}$ & $\begin{array}{l}-12.96^{* *} \\
-5.96 * * \\
-8.05 * *\end{array}$ & $\begin{array}{c}0.17 \\
-1.6 * * \\
2.82 * *\end{array}$ & $\begin{array}{c}11.84^{* *} \\
16.9^{* *} \\
16.33^{* *}\end{array}$ \\
\hline
\end{tabular}

Where: Crosses I, II and III were Sakha 101 x GZ1368s-5-4, Sakha 102 x IET1444 and Egyptian Yasmin x IR78875-176-B2-B, respectively.

*and **: Significant at $0.05,0.01$ probability levels, respectively.

$\mathrm{C}$ of scaling test was insignificant in all crosses, indicating the important of interaction components, i.e. additive $x$ additive (i), additive $x$ dominance (j) and dominance $\mathrm{x}$ dominance $(\mathrm{L})$ in the inheritance of grain yield per plant.

Table (2) illustrated that the mid parent value (m) and additive effect (d) was positively significant in the three studied crosses. The dominance (h) gene effect was either highly significant negative or positive in crosses, II and III, their estimated values were (-92.44 and39.24), respectively. Highly significant and negative estimates of additive $\mathrm{x}$ additive (i) type of gene interaction (-118.1) was recorded for grain yield per plant in the second cross, Sakha 102 x IET1444, in addition, it was controlled also by highly significant positive estimates (19.3) of additive $\mathrm{x}$ dominance type of gene interaction. Moreover, dominance $\mathrm{x}$ dominance (L) was highly significant in negative directions in crosses I and III, while it was positive in cross II, (Table 2). The results indicated that selection inlate generation will be very important to improve grain yield per plant. Similar results were reported by Abd El-Lattef et al. (2012) and Hassan et al. (2013). 


\section{Grain length ( $\mathrm{mm})$}

Data in Table (1) showed that values of A, B and C in the scaling test for grain length were highly significant in all studied crosses, except value of B in cross $\mathrm{I}$, indicating the important of interaction components, i.e. additive $\mathrm{x}$ additive (i), additive $x$ dominance $(j)$ and dominance $x$ dominance $(L)$ in the inheritance of grain length.

Table (2) indicated that mid parent value (m) was highly significant in positive direction in all crosses. The highest estimated value was recorded in cross II (7.85) followed by cross III (7.59) and cross I (5.86). Moreover, additive effect was highly significant in negative direction in cross II. In addition, the genetic parameters, dominance effect, additive $\mathrm{x}$ additive type of gene interaction were highly significant in negative direction in crosses, II and III. On the other hand, additive $\mathrm{x}$ dominance type of gene interaction was found to be highly significant in negative direction in cross I, while, dominance $\mathrm{x}$ dominance type of gene interaction was found to be highly significant in positive direction in crosses II and III. These results indicated that all types of gene interaction were played an important role in the inheritance of grain length according to the cross itself. These results were in agreement with El-Abd et al. (2009), Sultan et al. (2010), Abd El-Lattef et al. (2012) and Hassan et al. (2013).

\section{Grain shape:}

Data in Table (1) showed that the values of A, B and C of the scaling test for grain shape were highly significant in all studied crosses, indicating the important of interaction components, i.e. additive $x$ additive (i), additive $x$ dominance $(j)$ and dominance $x$ dominance $(L)$ in the inheritance of grain shape.

Table (2) showed that the mid parent value (m) was positively significant in the three studied crosses. On the other hand, additive effect (d) was either negative (-0.67) or positive (0.24 and 0.67$)$ and highly significant in crosses I, II and III, respectively, The genetic parameters, dominance effect (h) and additive $\mathrm{x}$ additive type of gene interaction (i) for grain shape were either positive or negative and high significant in crosses I and III, respectively. Moreover, additive $x$ dominance (j) type of gene interaction was either highly significant in positive direction in cross I or in negative direction in cross II. In addition, dominance $\mathrm{x}$ dominance (L) type of gene interaction was significantly in negative direction in crosses, I and II, while, it was highly significant in positive direction in cross III. The results indicated that the selection in late generations will be improving grain shape in cross II. Similar results were obtained previously by El-Abd et al. (2001), El-Abd et al. (2009) and Hassan et al. (2013). 


\section{Amylose content (\%):}

Data in Table (1) showed that values of A, B and C of the scaling test for amylose content \% were highly significant in all studied crosses, indicating the important of interaction components, i.e. additive $\mathrm{x}$ additive (i), additive $\mathrm{x}$ dominance $(\mathrm{j})$ and dominance $\mathrm{x}$ dominance $(\mathrm{L})$ in the inheritance of amylose content (\%).

Obviously, Table (2) shows that the mid parent value (m) and dominance $\mathrm{x}$ dominance type of gene interaction were positively significant in the three studied crosses. The additive (d) gene effect was highly significant in negative direction in cross II, while it was insignificant positive in other two crosses. Highly significant and negative estimates of both dominance gene effect and additive $\mathrm{x}$ additive (i) type of gene interaction were recorded for amylose content $\%$ in all the studied crosses. In addition, the rice crosses, Sakha 102 x IET1444 and Egyptian Yasmin x IR78875-176-B2-B were controlled by highly significant negative (-1.6) and positive (2.82) estimates of additive $\mathrm{x}$ dominance type of gene interaction, respectively. The results indicated that selection in late generation will be very important to improving amylose content \%. Similar results were reported by El-Abd et al. (2001), El-Hissewy (2004) and El-Abd et al. (2008).

\section{Estimates of genetic Variance, Heritability, and expected genetic advance: 1000 Grain weight $(\mathrm{gm})$ :}

Table (3) further showed that the estimates of additive genetic variance (D) were higher than that of the dominance genetic variance $(\mathrm{H})$ in crosses II and III,. These findings indicated that the additive genetic variance in cross II and III played major role than that of dominance genetic variance in the inheritance of 1000 grain weight character in the majority of these rice crosses, these results indicated also that additive variance played an important role in the inheritance of this character in these crosses. Similar results were obtained by El-Abd (2003), Mohan Lai and Chauhan (2011) and Basavaraja et al. (2013).

The broad sense heritabilities for the present trait were high, (85.51, 91.96 and 94.09) in the three studied crosses, I, II and III respectively. While, low values $(25.03,23.38$ and 19.86) were estimated in narrow sense heritability for the same crosses, alternatively, Table (5). However, the great discrepancy between the estimates of heritability in broad and narrow sense for 1000 grain weight character was reflected in low estimates of dominance variance or high estimates of additive variance for this trait. These finding were in close agreement with those reported earlier by Sreeparvathy et al. (2010), El-Gamal (2013) and Sathya and Jebaraj (2013). 
Table(3) Estimates of additive genetic variance $(1 / 2 \mathrm{D})$, dominance genetic variance $(1 / 4 \mathrm{H})$, broad and narrow-sense heritability and genetic advance (GS\%) for rice for the three studied crosses Characters.

\begin{tabular}{|c|c|c|c|c|c|c|}
\hline \multirow[b]{2}{*}{ Character } & \multirow[b]{2}{*}{ Cross } & \multicolumn{2}{|c|}{ Genetic variance } & \multicolumn{2}{|c|}{ Heritability } & \multirow{2}{*}{$\begin{array}{c}\text { GS } \\
\%\end{array}$} \\
\hline & & $\mathrm{D}$ & $\mathrm{H}$ & $\begin{array}{l}\text { Broad } \\
\text { sense }\end{array}$ & $\begin{array}{l}\text { Narrow } \\
\text { sense }\end{array}$ & \\
\hline $\begin{array}{l}1000 \text { grain weight } \\
\text { (gm) }\end{array}$ & $\begin{array}{c}\text { I } \\
\text { II } \\
\text { III }\end{array}$ & $\begin{array}{l}0.78 \\
1.44 \\
3.68\end{array}$ & $\begin{array}{c}-0.8 \\
-1.4 \\
-3.52\end{array}$ & $\begin{array}{l}85.51 \\
91.96 \\
94.09\end{array}$ & $\begin{array}{l}25.03 \\
23.38 \\
19.86\end{array}$ & $\begin{array}{c}9.04 \\
97.91 \\
12.777\end{array}$ \\
\hline $\begin{array}{l}\text { Grain yield / } \\
\text { plant } \backslash(\text { gm) }\end{array}$ & $\begin{array}{c}\text { I } \\
\text { II } \\
\text { III }\end{array}$ & $\begin{array}{c}43.9 \\
38.46 \\
32.88\end{array}$ & $\begin{array}{l}-40.24 \\
-34.44 \\
-34.32\end{array}$ & $\begin{array}{l}98.73 \\
95.91 \\
87.25\end{array}$ & $\begin{array}{l}17.74 \\
26.34 \\
17.49\end{array}$ & $\begin{array}{c}22.45 \\
25.784 \\
21.047\end{array}$ \\
\hline Grain length $(\mathrm{mm})$ & $\begin{array}{c}\text { I } \\
\text { II } \\
\text { III }\end{array}$ & $\begin{array}{c}0.188 \\
0.34 \\
0.52\end{array}$ & $\begin{array}{c}-0.18 \\
-0.328 \\
-0.44\end{array}$ & $\begin{array}{l}90.71 \\
91.70 \\
96.06\end{array}$ & $\begin{array}{l}26.58 \\
22.31 \\
35.37\end{array}$ & $\begin{array}{l}21.735 \\
18.109 \\
38.167\end{array}$ \\
\hline Grain shape & $\begin{array}{c}\text { I } \\
\text { II } \\
\text { III }\end{array}$ & $\begin{array}{l}0.088 \\
0.136 \\
0.154\end{array}$ & $\begin{array}{l}-0.044 \\
-0.128 \\
-0.132\end{array}$ & $\begin{array}{l}90.83 \\
92.96 \\
95.12\end{array}$ & $\begin{array}{c}19.73 \\
24.88 \\
32.5\end{array}$ & $\begin{array}{l}26.027 \\
48.612 \\
50.544\end{array}$ \\
\hline Amylose content $\%$ & $\begin{array}{c}\text { I } \\
\text { II } \\
\text { III }\end{array}$ & $\begin{array}{c}1.4 \\
1.88 \\
0.4\end{array}$ & $\begin{array}{c}-1.32 \\
-1.84 \\
-0.384\end{array}$ & $\begin{array}{c}96.6 \\
96.96 \\
88.71\end{array}$ & $\begin{array}{l}17.28 \\
10.42 \\
29.43\end{array}$ & $\begin{array}{l}9.036 \\
7.363 \\
9.729\end{array}$ \\
\hline
\end{tabular}

Where: Crosses I, II and III were Sakha 101 x GZ1368s-5-4, Sakha 102 x

IET1444 and Egyptian Yasmin x IR78875-176-B2-B, respectively.

Low estimates of expected genetic advance (9.04, 97.91 and 12.77) were observed in crosses, I, II and III, respectively. Low expected genetic advance with low narrow sense heritability for 1000 grain weight character could be expected because this trait is under polygenic control. Moreover, additive and dominance components of variation were significant in the inheritance of this trait, but additive component was higher than the dominance one. The results suggested that early generation selection may not be effective in improving of 1000 grain weight character in all crosses. Similar results were obtained earlier by El-Abd et al. (2007) and Ahmadikhah (2010).

\section{Grain yield per plant (gm):}

Data in Table (3) showed that additive genetic variance was higher than that of dominance genetic variance in the majority of the crosses I and II for grain yield per plant. The relative magnitude of the additive variance to dominance variance was dependent on the cross itself, it was 1.09 times than 
that of dominance variance in the cross I, namely, (Sakha 101 X GZ1368s-54), while it was reached 1.12 times than that of dominance variance in the cross II, namely, (Sakha $102 \mathrm{X}$ IET1444), while, it less than that of dominance variance in the cross III, namely, (Egyptian Yasmin X IR78875176-B2-B). This could lead to the conclusion that some breeding programs would be more effective and faster with certain crosses than with other crosses.

Heritability estimates in broad sense for this trait were high (98.73, 95.91 and 87.25) in the three studied crosses. Moreover, narrow sense heritability was low $(17.74,26.34$ and 17.49) in the all studied crosses respectively. The results were in harmony with that presented by El-Abd et al. (2007), Sreeparvathy et al. (2010) and Basavaraja et al. (2013).

The expected genetic advance under top $5 \%$ of selection were moderate (22.45, 25.78 and 21.04) in crosses I, II and cross III, respectively. These results indicated that the selection in early generation may be effective in improving of grain yield per plant character in all crosses. Similar results were exhibited by El-Abd et al. (2007), Karim et al. (2007) and Sathya and Jebaraj (2013).

\section{Grain length $(\mathrm{mm})$ :}

Table (3) shows that the estimates of additive genetic variance were higher than that of dominance genetic variance in the three studied crosses. The relative magnitude of the additive genetic variance was approximately ten times (or more than ten) that of dominance genetic variance in cross I while it was reached 1.037 times than that of dominance variance in the cross II and 1.2 in the cross III. This finding indicated that the additive variance played an important role than the dominance variance in the inheritance of grain length character in the majority of the rice crosse I. Similar results were obtained by El-Abd (2003) and Kishore et al. (2008).

High estimates of heritability in broad sense (90.71, 91.70 and 96.06) were observed in the three studied crosses, respectively, Table (3). However, the same crosses gave moderate estimates of heritability in narrow sense, their estimated values were $(26.58,22.31$ and 35.37$)$, respectively. These results were in agreement with those obtained by the partitioning of the genetic variance. These results also were in agreement with those reported by Singh et al. (2006) and Bharadwaj et al. (2007).

Moderate estimates of expected genetic advance were observed in the three studied crosses, $(21.735,18.109$ and 38.176), respectively. High heritability coupled with moderate genetic advance indicated that additive type of gene action was played a significant role in the expression of this character. It was suggested that selection may be effective in improving this 
trait in early segregation. On the contrary, high expected genetic advance were estimated by El-Abd (2003) and Asfaliza et al. (2012).

\section{Grain shape:}

Table (3) reveals that high estimates of additive genetic variance (D) were computed for each of the three studied crosses in comparison with their corresponding estimates of dominance genetic variance $(\mathrm{H})$. The relative magnitude of the additive genetic variance was 2.0, 1.06 and 1.17 times more than dominance genetic variance in all crosses. This finding illustrated that additive variance played a major role than the dominance variance in the inheritance of grain shape character. This in turn, suggested that rice breeding programs could be effective for improving such trait. Similar results were detected previously by El-Abd (2003), Singh et al. (2006) and Bharadwaj et al. (2007).

High broad sense heritability were recorded in the three studied crosses, it was varied from $(90.83$, in cross, I) to (95.12 in cross, III). On the other hand, moderate estimates of narrow sense heritability (19.73, 24.88 and 32.5) were observed for all the studied crosses, respectively. These findings indicate that selection for this trait could be effective in early generation. These results were in harmony with those of Bharadwaj et al. (2007), El-Abd et al. (2008) and Veerabadhiran et al. (2009).

Moreover, the expected genetic advance were ranged between moderate and high $(26.027,48.612$ and 50.544) in crosses, I, II and cross III, respectively. Furthermore, the estimates of high heritability coupled with high expected genetic advance, could be indicated that selection for grain shape in early generation would be effective for improving grain shape character in all crosses. These results were similar to those obtained by Sarawgi et al. (2000), Mohan Lai and Chauhan (2011) and Asfaliza et al. (2012).

Amylose content \%:

From the data presented in Table (3) it appeared that the relative magnitude of the additive genetic variance was higher than that of dominance genetic variance in the majority of the three studied crosses for amylose content $\%$. The estimates of additive genetic variance were reached $1.06,1.42$ aand 1.05 times than that of dominance genetic variance in all the studied crosses, respectively. Heritability estimates in broad sense for this trait was high $(96.60,96.96$ and 88.71) in the three studied crosses, respectively. Meanwhile, narrow sense heritability was low $(17.28,10.42$ and 29.43) in all the studied crosses, respectively.

The excepted gain from selection was low $(9.036,7.363$ and 9.729) in crosses, I, II and III, respectively, indicating that the selection in early generation may be not effective in improving amylose content $\%$ character. 
These findings were contradicted with those obtained previously by ElAbd (2003), Veerabadhiran et al. (2009) and Karladee et al. (2012).

Conclusively, the results suggested that early generation selection may be effective in improving of these traits in cross I. On the other hand, the results also indicated that the selection in late generations will be improving grain shape in cross II and 1000 grain weight in cross III.

\section{REFERENCE}

Abd El-Lattef, A. S.; A. A. B. Abo-Khalifa and A. A. A. El-Gohary. 2012. Inheritance of some quantitative characters under drought conditions in rice (Oryza sativa L.). International Journal of Biology, Pharmacy and Allied Sciences (IJBPAS), June, 2012, 1(5): 620-635.

Ahmadikhah, A. 2010. Study on selection effect, genetic advance and genetic parameters in rice. Annals of Biological Research.1(4):45-51.

Akram, M.; M. Munir; Saifullah Ajmal; Shaukat Mehmud; Yahya Ashraf. 2007. Combining ability analysis for yield and yield components in rice (Oryza sativa L.). Pakistan Journal of Agricultural Research, 20(1/2):11-14.

Asfaliza, R.; M. Y Rafii; G. Saleh; O. Omar; A. Puteh. 2012. Combining ability and heritability of selected rice varieties for grain quality traits. Australian Journal of Crop Science, 6(12):1718-1723.

Basavaraja, T.; M. Asif; S. K. Mallikarjun and S. Gangaprasad. 2013. Variability, heritability and genetic advance for yield and yield attributing characters in different local rice (Oryza sativa L.) cultivars. Asian Journal of Bio Science, 8(1):60-62.

Bharadwaj, C.; Rajesh Mishra; C. T. Satyavathi; S. K. Rao and K. S. Kumar. 2007. Genetic variability heritability and genetic advance in some new plant type based crosses of rice (Oryza sativa L.). Indian Journal of Agricultural Research. 41(3):189-194.

Botany, W. T. 1961. Mass emasculation in rice. Inster. Rice Comm. Newsletter., 9:9-13.

El-Abd, A. B. 2003. Genetic variability, heritability and associations between yield attributes and grain quality traits in rice (Oryza sativa L.). Egypt. $J$. Plant Breed., Proceed. Third Pl. Breed. Conf., April 26, Special Issue. 7(1):7-22.

El-Abd, A. B.; A. A. Abd-Allah; S. M. Shehata; A. S. M. Abd El-Lateef and B. A. Zayed. 2007. Heterosis and combining ability for yield and its components and some root characters in rice under water stress conditions. Egypt. J. Plant Breed., Proceed. Fifth Pl. Breed. Conf., May 27, Special Issue. 11(2):593-609. 
El-Abd, A. B.; A. A. El-Hissewy; A. I. El-Agamy; S. A. Shafey. 2001. A study on the nature of gene action in the inheritance of some cooking and eating quality characters in rice (Oryza sativa L.). Rice genetic resources and breeding for Europe and other temperate areas. Proceedings of Eurorice Symposium. 3-8 September, Krasnodar, Russia, 1-10.

El-Abd, A. B.; I. M. O. El-Rewainy; M. A. El-Banna and A. M. ElEkhtyar. 2008. Studies on the nature of gene action controlling rice grain quality and mineral content. Proceedings (the Second Field Crops Conference). PCRI, ARC, Giza, Egypt, 14-16 Oct. 2008 157-176.

El-Abd, A. B.; M. Sh. El-Keredy; M. S. Abd El-Aty and H. M. Hassan 2009 Detection of epistasis and estimation of additive and dominance components of genetic variation using triple test cross analysis in rice(Oryza sativa L.). 6th International Plant Breeding Conference, Ismailia, Egypt, May 3-5: 631-647.

El-Gamal, W.H. 2013. Inheritance of some traits related to drought tolerance in rice. Ph.D. Thesis, Fac. of Agricultural, Mansoura Univ., Egypt.

El-Hissewy, A. A. 2004. A breeding study on some grain quality characters of rice (Oryza sativa L). Egyptian Journal of Agricultural Research. 82(1):91-100.

Hallauer, A. R. and J. B. Miranda. 1988. Quantitative Genetics in Maize Breeding. Second edition. Iowa State University Press, Ames, Iowa.

Hanson, C. H.; H. F. Robinson and Comstock. 1956. Biometrical studies yield segregating of Korean Lespedeza. Agron. J., 48:268-272.

Hassan, H. M.; A. B. El-Abd; Gimmy Lamo and N. M. El Baghdady. 2013. Inheritance of grain quality and yield traits in rice using triple test cross analysis. Egypt. J. Plant Breed., 17:(2) 147-161.

Hayman, B. I. 1958. The separation of epistatic from additive and dominance variation means. Heredity, 12:371-390.

Hayman, B. I. and K. Mather. 1955. The description of genetic interaction in continuous variation. Biometrics, 11:69-82.

IRRI 1996. International Rice Research Institute. Standard evaluation System for Rice. P. O. Box 933, 1099 Manila, Philippines.

Jodon, N. E. 1938. Experiment on artificial hybridization of rice. J. Amer. Soci. Argon., 30:249-305.

Johnson, H. W.; H. F. Robinson and R. E. Commstock. 1955. Estimates of genetic and environmental variability in soybean. Agron. J., 47:214-222.

Karim, D.; U. Sarkar; M. N. A. Siddique; M. A. K. Miah and M. Z. Hasnat. 2007. Variability and genetic parameter analysis in aromatic rice. International Journal of Sustainable Crop Production, 2(5):15-18.

Karladee, D.; A. Gavilo and S. Jamjod. 2012. Early generation selection for amylose content in rice grain: heritability and response to selection. Chiang Mai University Journal of Natural Sciences, 11(1):87-96. 
Kishore, N. S.; V. R. Babu; N. A. Ansari and A. R. Prasad. 2008. Genetic variability, heritability and genetic advance in rice (Oryza sativa L.) genotypes of different eco-geographical regions. Research on Crops. 9(1):147-150.

Mather, K. 1949. Biometrical Genetic. Dover Publication, inc. London.

Mohan Lai and D. K. Chauhan. 2011. Studies of genetic variability, heritability and genetic advance in relation to yield traits in rice. Agricultural Science Digest. 31(3):220-222.

Onyia, V. N. 2011. Combining ability analysis for yield and yield components in eight breeding lines of rice (Oryza sativa L.). Agro-Science, 10(2):7-15.

Powers, L. R.; L. F. Locke and J. C. Garrett. 1950. Partitioning method of genetic analysis applied to quantitative characters of tomato crosses. U. S. Dept. Agr. Tech. Bull., 998:56 Pp.

RRTC. 2013. The Thirteen National Rice Research and Development Program Workshop. RRTC., ARC., Egypt. pp. 45.

Sarawgi, A. K.; N. K. Rastogi and D. K. Soni. 2000. Studies on some quality parameters of indigenous rice in Madhya Pradesh. Annals of Agricultural Research. 21(2):258-261.

Sathya, R. and S. Jebaraj. 2013. Heritability and genetic advance estimates from three line rice hybrids under aerobic condition. International Journal of Agricultural Science and Research (IJASR), 3(3):69-74.

Shehata, S. M.; A. B. El-Abd; A. S. M. Abd El-Lattef and E. A. S. Badr. 2009. Combining ability for grain yield and brown spot disease resistance traits in rice (Oryza sativa L.) under saline soil conditions. J. Agric Sci., Mansoura Univ., 34(3):2017-2039.

Singh, S. P.; R. P. Singh; K. Srinivasulu and J. P. Prasad. 2006. Studies on genetic variability, character association in diverse lines of international irrigated observation nursery of rice (Oryza sativa L.). Research on Crops, 7(3):714-719.

Snedecor, G.W. and W. G. Cochran. 1967. Statistical Methods. $6^{\text {th }}$ ed. Iowa State University Press, Amer, Iowa, USA.

Sreeparvathy, P. V.; R. D. Vashi and V. C. Kodappully. 2010. Genetic variability, heritability and genetic advance in rice, Oryza sativa. Journal of Ecobiology, 26(3/4):205-210.

Sultan, M. S.; M. A. Andel-Moneam; A. B. El-Abd and S. A. El-Naem. 2010. Genetic behavior and combining ability for some traits of root, physiological and grain quality traits in rice under water stress conditions. J. Plant Prod., Mansoura Univ., Vol. 1(12):1721-1734.

Veerabadhiran, P.; M. Umadevi and R. Pushpam. 2009. Genetic variability, heritability and genetic advance of grain quality in hybrid rice. Madras Agricultural Journal, 96(1/6):95-99. 
Warner, J. N. 1952. A method for estimating heritability. Agron. Journal, 44:427-430.

\section{توارث بعض صفات المحصول وصفات جودة الحبوب في الأرز}

*خالد فتحى سالم *- يس محمد يس **- عبد المعطى بسيونى العبد *-

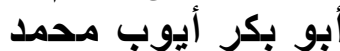

*قسم البيوتكذولجيا النباتية- معهد بحوث الهندسة الوراثية و التكنولوجيا

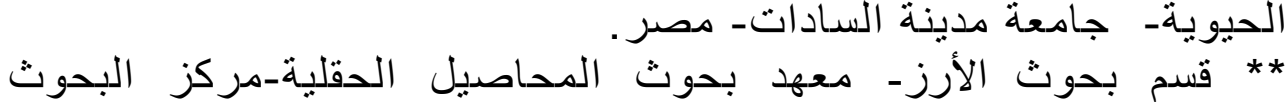

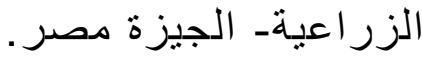

أجريت هذه الدراسة في مزر عة مركزا لبحوث و التدريب في الأرز - سخاـ

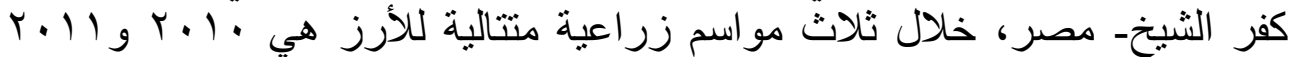

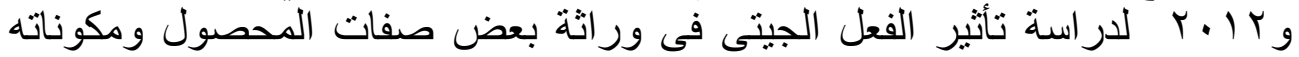
وبعض صفات جودة الحبوب في الأرز تحت الظروف الطبيعية، ومادة هذه الدر اسة التهات

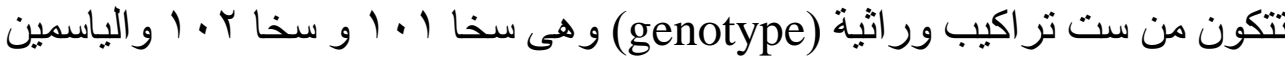

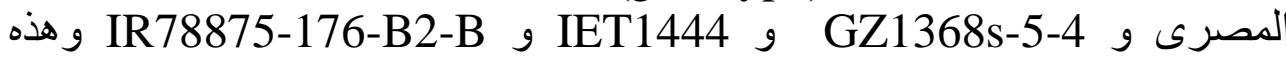
التر اكيب الور اثية الست ذات مدى واسع من التباينات الور اثية متو افق مع هذه الخلفية

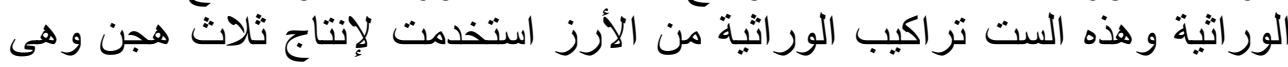

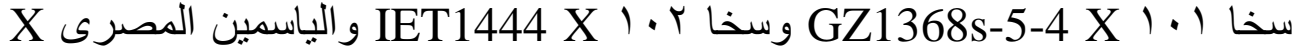
IR78875-176-B2-B حيث كانت الست عشائر هى الأب الأول (P1) الأب

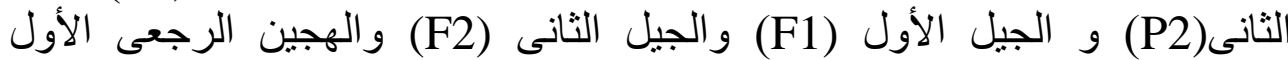
والهجين الرجعى الثانى (BC21)

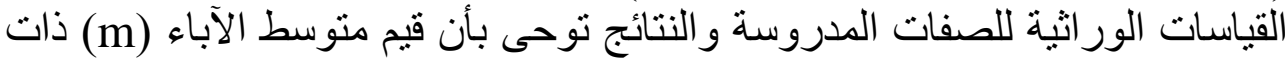

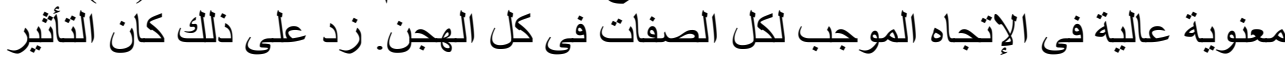

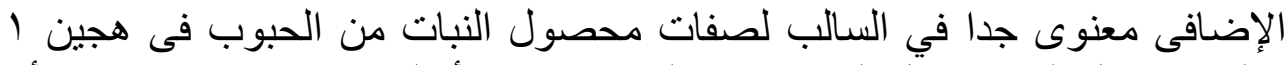

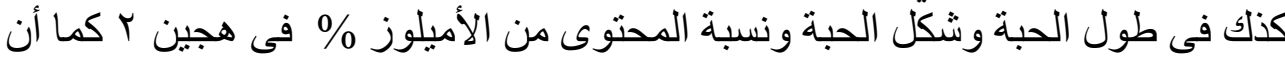

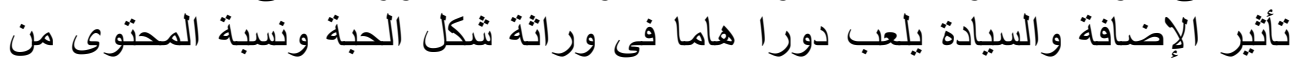
الأميلوز \% فى الإتجاه السالب ومحصول النبات من الحبوب فى الإتجاه الموجب فى في

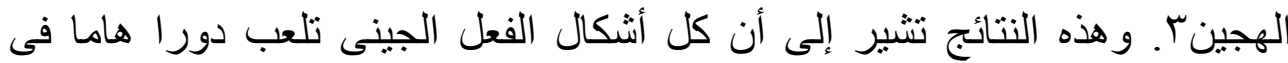
توارث كل الصفات مع نفس الهجن.

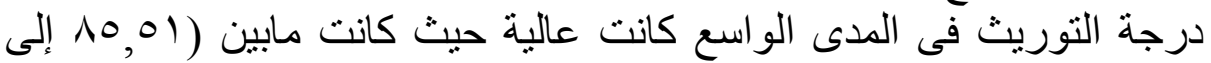

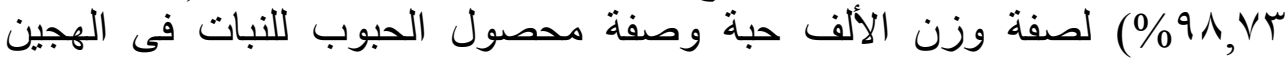


ابالترتيب. زد على ذللك أنها كانت منخفضة إلى متوسطة القيم فى المدى الضيق

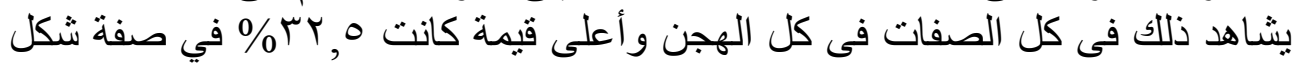

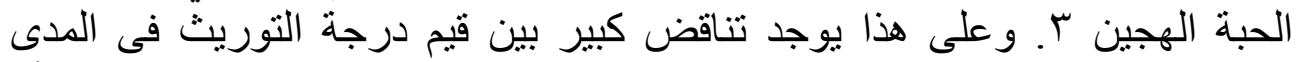

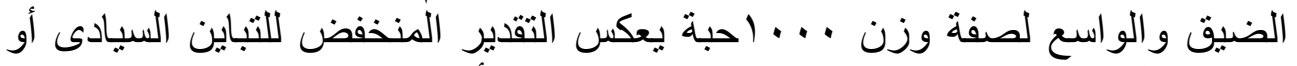

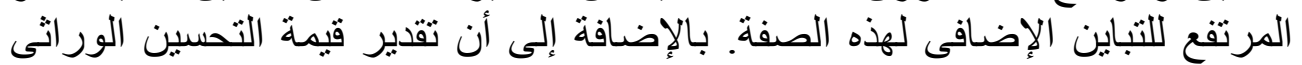

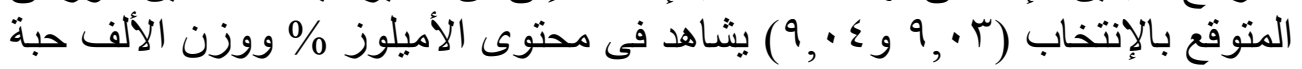

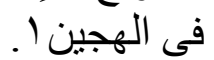

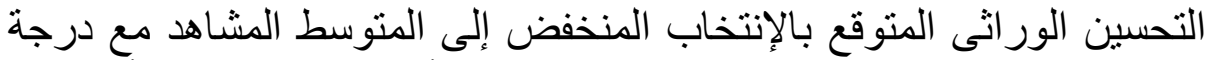

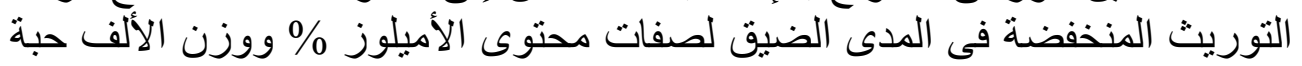

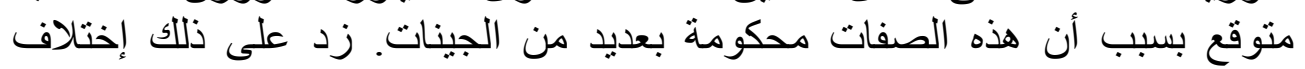

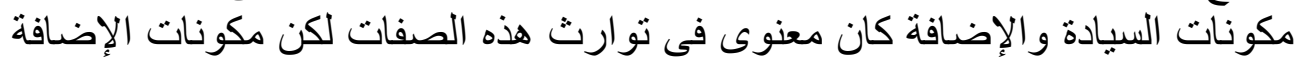

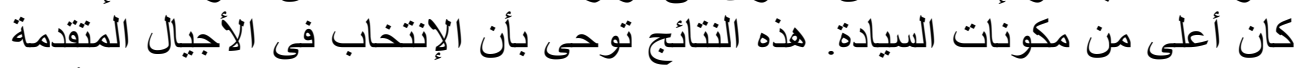

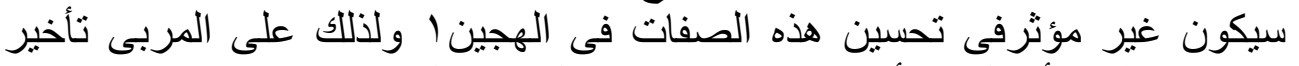

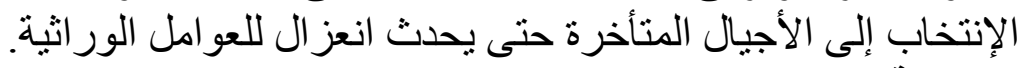

